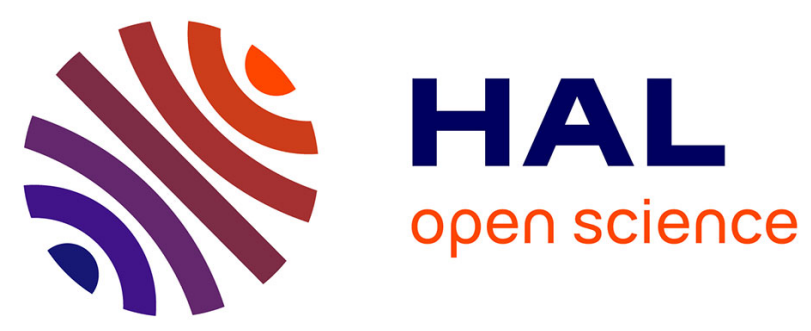

\title{
Metabolism in orange fruits is driven by photooxidative stress in the leaves
}

Florine Poiroux-Gonord, Jérémie Santini, Anne-Laure Fanciullino, Félicie

Lopez-Lauri, Jean Giannettini, Huguette Sallanon, Liliane Berti, Laurent

Urban

\section{To cite this version:}

Florine Poiroux-Gonord, Jérémie Santini, Anne-Laure Fanciullino, Félicie Lopez-Lauri, Jean Giannettini, et al.. Metabolism in orange fruits is driven by photooxidative stress in the leaves. Physiologia Plantarum, 2013, 149 (2), pp.175-187. 10.1111/ppl.12023 . hal-00789965

\section{HAL Id: hal-00789965 \\ https: / hal-univ-corse.archives-ouvertes.fr/hal-00789965}

Submitted on 6 Mar 2013

HAL is a multi-disciplinary open access archive for the deposit and dissemination of scientific research documents, whether they are published or not. The documents may come from teaching and research institutions in France or abroad, or from public or private research centers.
L'archive ouverte pluridisciplinaire HAL, est destinée au dépôt et à la diffusion de documents scientifiques de niveau recherche, publiés ou non, émanant des établissements d'enseignement et de recherche français ou étrangers, des laboratoires publics ou privés. 


\title{
Metabolism in orange fruits is driven by photooxidative stress in the leaves
}

\author{
Florine Poiroux-Gonord ${ }^{\mathrm{a}}$, Jérémie Santini ${ }^{\mathrm{a}, \mathrm{b}}$, Anne-Laure Fanciullino ${ }^{\mathrm{a}, \mathrm{c}}$, Félicie Lopez- \\ Lauri $^{\mathrm{d}}$, Jean Giannettini ${ }^{\mathrm{b}}$, Huguette Sallanon ${ }^{\mathrm{d}}$, Liliane Berti ${ }^{\mathrm{b}}$ and Laurent Urban ${ }^{\mathrm{d} * *}$
}

${ }^{a}$ INRA - UR 1103 Génétique et Ecophysiologie de la Qualité des Agrumes, F-20230 San Giuliano, France

${ }^{b}$ UMR CNRS 6134, Laboratoire Biochimie et Biologie Moléculaire du Végétal, Quartier Grossetti, BP52, F-20250 Corte, France

'INRA - UR 1115 Plantes et Systèmes de culture Horticoles, Site Agroparc, F-84914 Avignon Cedex

9, France

${ }^{\mathrm{d}}$ Laboratoire de Physiologie des Fruits et Légumes, Université d'Avignon et des Pays du Vaucluse, Bât Agrosciences, 301 rue Baruch de Spinoza, BP 21239, F-84916 Avignon Cedex 9, France

*Corresponding author, e-mail: laurent.urban@univ-avignon.fr

Received 27 September 2012; revised 18 December 2012

This article has been accepted for publication and undergone full peer review but has not been through the copyediting, typesetting, pagination and proofreading process, which may lead to differences between this version and the Version of Record. Please cite this article as doi: $10.1111 / \mathrm{ppl} .12023$

(C) 2013 Scandinavian Plant Physiology Society, ISSN 0031-9317 
In plants, stress signals propagate to trigger distant responses and thus stress acclimation in nonexposed organs. We tested here the hypothesis that leaves submitted to photooxidative stress may influence the metabolism of nearby fruits and thus quality criteria. Leaves of orange trees (Citrus sinensis (L.) Osbeck cv. 'Navelate') were acclimated to shade for one week and then submitted to full and medium light conditions. As expected, photoinhibition was detected in leaves of both full and medium light treatments as revealed by stress indicators $\left(\mathrm{F}_{\mathrm{v}} / \mathrm{F}_{\mathrm{m}}\right.$, Performance Index $)$ for at least 99 hours after treatments. In the fruits near the stressed leaves, we then determined the activities of enzymes related to oxidative stress, superoxide dismutase, catalase and the enzymes of the ascorbate/glutathione cycle, as well as the contents in sugars, organic acids and carotenoids. Ascorbate peroxidase and monodehydroascorbate reductase activities in the pulp of fruits were dramatically higher in both treatments when compared to the control. Ascorbate and total sugars were not affected by the photooxidative stress. However, the full light treatment resulted in a $16 \%$ increase in total organic acids, with succinic acid being the major contributor, a shift towards less glucose+fructose and more sucrose, and a $15 \%$ increase in total carotenoids, with cis-violaxanthin being the major contributor. Our observations strongly suggest the existence of a signal generated in leaves in consequence of photooxidative stress, transmitted to nearby fruits. Exploiting such a signal by agronomic means promises exciting perspectives in managing quality criteria in fruits accumulating carotenoids.

Abbreviations - AA, ascorbate; ABA, abscisic acid; APX, ascorbate peroxidase; BHT, tertbutylhydroxytoluene; C, control; CAT, catalase; DHA, dehydroascorbate; DHAR, dehydroascorbate reductase; DETAPAC, diethylenetriaminepentaacetic; FL, full light; $\mathrm{F}_{\mathrm{v}} / \mathrm{F}_{\mathrm{m}}$, maximum quantum yield of photosystem II; $\mathrm{F}_{\mathrm{v}} / \mathrm{F}_{\mathrm{o}}$ : variable on minimum fluorescence ratio; $\mathrm{FW}$, fresh weight; GR, glutathione reductase; GSH, glutathione; GSSG, glutathione disulfide; JA, jasmonic acid; MDHAR, monodehydroascorbate reductase; MEP, 2-C-methyl-D-erythritol 4-phosphate; ML, medium light intensity; MnSOD: manganese superoxide dismutase; MTBE, methyl tert-butyl ether; NBT, nitroblue tetrazolium; NPR1, nonexpressor of pathogenesis-related genes 1; PCA, principal component analysis; PDS, phytoene desaturase; PI, performance index; PSY, phytoene synthase; PSII, photosystem II; RC/ABS, chlorophyll fluorescence parameters related to the density of active reaction center on a chlorophyll basis; ROS, reactive oxygen species; SA, salicylic acid; SAA, systemic acquired acclimation; SAR, systemic acquired resistance; SOD, superoxide dismutase; TGA1, teosinte glume architecture $1 ;\left(1-\mathrm{V}_{\mathrm{j}}\right) / \mathrm{V}_{\mathrm{j}}$, chlorophyll fluorescence parameters related to the dark reactions. 


\section{Introduction}

Improving fruit quality represents a major challenge for human health. In addition to the usual criteria, i.e. size, sugar content and acidity, consumers tend to pay more and more attention to criteria such as flavor and health benefits. Fruits represent a major source of vitamins and secondary metabolites, the so-called phytochemicals. Although there is a debate about the way secondary metabolites impact human health, there is a general consensus that the much praised health benefits of fruits and vegetables are, at least partially, attributable to their high concentrations in phytochemicals. Within this view it makes sense to try to produce fruits and vegetables with increased or guaranteed concentrations in phytochemicals. There have been numerous attempts to achieve this goal through conventional breeding and metabolic engineering (Newell-McGloughlin 2008). More recently it has been advocated that environmental levers offer also exciting perspectives to increase the concentrations in phytochemicals of fruits and vegetables (Poiroux-Gonord et al. 2010). Indeed, purely agronomic approaches can be very effective for a large range of secondary metabolites and, to a lesser extent, ascorbic acid. Among all the environmental factors liable to influence the metabolism of phytochemicals, moderate stress emerges as especially promising, because of its stimulating effect on biosynthesis of phytochemicals with little effect on yield, and also because stressing conditions can be easily imposed by growers, even in field conditions.

The way stresses influence the metabolism of phytochemicals can be summarized the following way. Arguably all stresses result in oxidative stress, i.e. the production of reactive oxygen species (ROS) (Grassmann et al. 2002); furthermore, ROS regulate directly or indirectly biosynthetic pathways of phytochemicals, which makes sense considering that: i) ascorbate and many secondary metabolites are strong antioxidants (Mittler 2002) ; ii) flavonoids reduce the risk of photooxidative stress by acting as sunscreens which reduce the quantity of energy absorbed by photosynthetic organs and tissues (Tattini et al. 2004) ; iii) some carotenoids play a central role in the dissipation of absorbed energy in excess in photosynthetic tissues through the so-called xanthophyll cycle (Demmig-Adams and Adams 1996). The role played by ROS or the variations in redox status associated to their production in the synthesis of phytochemicals raises a very intriguing question in fruits. If we consider that stress-induced ROS, or the associated variations in redox status, play a key-role in controlling biosynthesis of phytochemicals in the pulp of fruits, as suggested by several studies (Bouvier et al. 1998, Kuntz et al. 1998), then where do the ROS or redox signals come from? At the time of maturation, when chloroplasts have been converted into chromoplasts, they cannot originate from photosynthesis since the pulp has lost its photosynthetic machinery. Could they possibly proceed directly or indirectly from stressed leaves close to them?

The idea that leaves under pathogen or insect attack can be at the origin of a signal transmitted towards other plant parts, triggering adaptative responses, has been extensively studied, leading to the concept of systemic acquired resistance (SAR). SAR refers to a distinct signal transduction pathway that plays an important role in the ability of plants to defend themselves against pathogens (Ryals et 
al. 1996). Systemic acquired acclimation (SAA) is a more recent and much less documented concept. The first evidence for systemic signaling was presented by Karpinski et al. (1999) on non-stressed leaves, distant from leaves exposed to photooxidative stress conditions. Following the seminal work of Karpinski et al. (1999), Rossel et al. (2007) observed in non-stressed tissues of Arabidopsis thaliana the rapid induction of ZAT10, a zinc finger transcription factor involved in salt, drought and cold response, along with numerous other high-light inducible genes, thus providing conclusive evidence for the existence of systemic acquired acclimation.

So far, the hypothesis has not been tested that leaves submitted to photooxidative stress may also influence the metabolism of fruits and thus potentially quality criteria. This paper presents the first results showing that the antioxidant metabolism, and both the primary and secondary metabolisms are influenced in the pulp of orange fruits when photooxidative stress is imposed to nearby leaves. Our results thus support the hypothesis of a signal transmitted from leaves to fruits, and also suggest that photooxidative stress can be used to increase the concentration of carotenoids in fruits.

\section{Materials and methods}

\section{Plant material and experimental design}

Measurements were performed on fruits from 15-year-old trees of 'Navelate' orange trees (Citrus sinensis (L.) Osbeck) of similar age, growing under identical conditions. The trees, grafted on Poncirus trifoliata (L.) Raf., were randomly selected within an experimental orchard of the Station de Recherche Agronomique (INRA/CIRAD) near San Giuliano in Corsica (42 $18^{\prime} 55^{\prime \prime} \mathrm{N}, 9^{\circ} 29^{\prime} 29^{\prime \prime}$

E; $51 \mathrm{~m}$ a.s.1.). Trees were about $2.5 \mathrm{~m}$ high, and were spaced at $4 \times 6 \mathrm{~m}$. Water was supplied every day on the basis of $100 \%$ replacement of actual evapotranspiration estimated from the equation of Penman-Monteith (1965). Fertilizers were supplied and insects and diseases controlled according to the recommendations of the local department of agriculture.

Forty-eight fruiting branches composed of shoots of less than one year were selected among the experimental trees for being similar in light exposure and initial stem diameter (about $1 \mathrm{~cm}$ ). All branches had the same south orientation and a similar height above ground (about $1.5 \mathrm{~m}$ ). The branches were girdled at 40 leaves, before the beginning of the experiment, on 3 Feb. 2009. This high ratio was chosen so as to ensure that carbon supply was truly non-limiting. Girdling consisted in removing a $10 \mathrm{~mm}$ wide band of bark in the middle of the main stem of each selected branch to prevent any movement of assimilates between the branch and the rest of the tree. Leaves were all fully developed at the time of girdling. Vegetative flushing after girdling was exceptional and all new buds were removed. Moreover no fruit drop was observed during the course of the trial. At the onset of the experiment, fruits had entered the maturation phase. At that stage, chloroplasts were all replaced by chromoplasts in the pulp of fruits. Treatments were randomly allocated among the 4 selected trees of the trial. We used two shade cloths allowing respectively the actual transmission of $9.2 \%$ light $(90 \%$ shade cloth) and $81.8 \%$ light (20\% shade cloth). We checked that spectrums were not modified by 
shading, using a Li-Cor Li-1800 spectrometer. Ten leaves, the nearest to the fruit, were shaded using the $90 \%$ shade cloth. After one week of adaptation $(\mathrm{d}=0)$, two treatments were applied, one at high (FL, corresponding to full light) and the other at medium (ML) light intensity. The leaves of sixteen branches were completely uncovered and received full light. This treatment corresponds to the high light intensity treatment (FL). The leaves of another sixteen branches were covered using the $20 \%$ shade cloth. This treatment corresponds to the medium light intensity treatment (ML). Eventually, the leaves of sixteen branches were kept covered by the $90 \%$ shade cloth. This last treatment corresponds to the control (C). No fruits were ever shaded in the trial. Four samples of fruits of each treatment were harvested after 3, 27, 51 and 99 hours, at $11 \mathrm{~h} 00$ in the morning. At that time of the day, global radiation ranged from 40 to $178 \mu \mathrm{mol}$ photons $\mathrm{m}^{-2} \mathrm{~s}^{-1}$. Immediately after harvest, the pulp of fruit samples was ground in fine powder in liquid nitrogen and placed in sealed amber vials under nitrogen and kept frozen at $-80^{\circ} \mathrm{C}$ for further analysis.

Five days before $\mathrm{d}=0$, at $\mathrm{d}=0$ (before the light exposition), $\mathrm{d}=+2, \mathrm{~d}=+3$ and $\mathrm{d}=+4$, the maximum quantum yield of photosystem II $\left(\mathrm{F}_{\mathrm{v}} / \mathrm{F}_{\mathrm{m}}\right)$, and the performance index (PI) of Strasser et al. (2000), and its components $\left(\mathrm{F}_{\mathrm{v}} / \mathrm{F}_{0}, \mathrm{RC} / \mathrm{ABS},\left(1-\mathrm{V}_{\mathrm{J}}\right) / \mathrm{V}_{\mathrm{J}}\right)$ were measured on 15 leaves at 10 a.m. using a portable system (handyPEA, Hansatech, Norfolk, England). Before the trial, the same measurements were performed to ensure that there were differences between leaves from the different branches (data not shown).

During the experiment, meteorological data, temperatures, rainfalls and daily global radiation, were collected (Table 1).

\section{Determination of hydrogen peroxide content}

Hydrogen peroxide levels were determined as described by Velikova et al. (2000). Frozen fruit powder $(0.25 \mathrm{~g})$ was homogenized in an ice bath with $5 \mathrm{~mL}$ of $0.1 \%$ trichloroacetic acid (TCA). The homogenate was centrifuged at $12000 \mathrm{~g}$ for $5 \mathrm{~min}$ at $4^{\circ} \mathrm{C} .500 \mu \mathrm{L}$ of the supernatant was added to $500 \mu \mathrm{L}$ of $10 \mathrm{mM}$ of potassium buffer $(\mathrm{pH} 7.0)$ and $1 \mathrm{~mL}$ of $1 \mathrm{M}$ of potassium iodide. Commercial $\mathrm{H}_{2} \mathrm{O}_{2}$ was used to generate a standard curve. The mix was briefly shaken, and incubated at room temperature without light for $30 \mathrm{~min}$ before reading of the absorbance at $390 \mathrm{~nm}$, using a spectrophotometer Specord 205 (Analytic Iena, Wembley, UK). The value for non-specific absorbance was subtracted from the value obtained in the presence of KI. The content of $\mathrm{H}_{2} \mathrm{O}_{2}$ was determined using the standard curve.

\section{Determination of ascorbate and dehydroascorbate contents}

Total ascorbate (AA and DHA) and ascorbate (AA) contents were measured according to the method of Gillespie and Ainsworth (2007). A $0.150 \mathrm{~g}$ sample of frozen fruit powder was homogenized in 3 $\mathrm{mL}$ of cold $6 \%(\mathrm{w}: \mathrm{v})$ trichloroacetic acid (TCA). The homogenate was centrifuged at $13000 \mathrm{~g}$ for 5 min at $4{ }^{\circ} \mathrm{C}$. The supernatant was used for total ascorbate and AA determination. For measurements of 
total ascorbate, $500 \mu \mathrm{L}$ of extract was added to $100 \mu \mathrm{L}$ of $75 \mathrm{mM}$ phosphate buffer (pH 7), $200 \mu \mathrm{L}$ of $6 \%$ TCA and $100 \mu \mathrm{L}$ of $10 \mathrm{mM}$ of DL-dithiothreitol (DTT). After incubation for $10 \mathrm{~min}$ at room temperature, $100 \mu \mathrm{L}$ of $0.5 \%$ (w:v) N-ethylmaleimide (NEM) was added with additional incubation for at least $30 \mathrm{~s}$ at room temperature to remove excess DTT. It was followed by the addition of $1.5 \mathrm{~mL}$ of a reagent prepared just before use, by mixing $500 \mu \mathrm{L}$ of $10 \%$ TCA, $400 \mu \mathrm{L}$ of $43 \%$ (v:v) of orthophosphoric acid $\left(\mathrm{H}_{3} \mathrm{PO}_{4}\right), 400 \mu \mathrm{L}$ of $4 \%$ (w:v) 2,2-bypiridyl dissolved in ethanol $70 \%$ and 200 $\mu \mathrm{L}$ of $3 \%(\mathrm{w}: \mathrm{v})$ ferric chloride. After further incubation for 1 hour at $37^{\circ} \mathrm{C}$, the absorbance was measured at $525 \mathrm{~nm}$ in a spectrophotometer Specord 205 (Analytic jena, Wembley, UK). For AA determination, the same reaction was used but $200 \mu \mathrm{L}$ of phosphate buffer $(\mathrm{pH}=7)$ were used in place of DTT and NEM. The amount of DHA was estimated from the difference between total ascorbate and AA. Commercial L-ascorbic acid was used to generate a standard curve.

\section{Antioxidant enzyme activities}

\section{Sample preparation}

$1 \mathrm{~g}$ of orange pulp was homogenized in $5 \mathrm{~mL}$ of $50 \mathrm{mM}$ potassium phosphate buffer (pH 7.8) (Jing et al. 2009, Zhu et al. 2009) by 30 vertical strokes in a Dounce homogenizer. The homogenate was filtered and centrifuged at $4^{\circ} \mathrm{C}$ and $500 \mathrm{~g}$ for $10 \mathrm{~min}$ to eliminate nuclei, intact cells and cellular debris. The supernatant was then centrifuged at $4^{\circ} \mathrm{C}$ and $5000 \mathrm{~g}$ for $15 \mathrm{~min}$ in order to exclude chromoplasts. The supernatant obtained was centrifuged at $4^{\circ} \mathrm{c}$ and $13000 \mathrm{~g}$ for $30 \mathrm{~min}$ and then used as a crude extract for protein and enzyme analysis.

Superoxide dismutase (SOD; EC 1.15.1.1) and Manganese superoxide dismutase (MnSOD) assay SOD activity was measured using a modified method of Oberley and Spitz (1984). $100 \mu 1$ of extract was added to $800 \mu \mathrm{L}$ of a solution containing $1 \mathrm{mM}$ Diethylenetriaminepentaacetic acid (DETAPAC) buffer (pH 7.8), 1.25 Units catalase, $0.07 \mathrm{mM}$ nitroblue tetrazolium (NBT), $0.2 \mathrm{mM}$ xanthine. The reaction was initiated by adding $100 \mu \mathrm{L}$ of 0.104 Units of xanthine oxidase. For MnSOD, the same protocol was used, but in the presence of $6.2 \mathrm{mM}$ sodium cyanide. One unit of SOD was defined as the amount of enzyme required to cause a $50 \%$ inhibition of the rate of NBT reduction at $560 \mathrm{~nm}$, at $25^{\circ} \mathrm{C}$.

Catalase assay (CAT; EC 1.11.1.6)

CAT activity was measured according to the method of Aebi (1984). The reaction mixture $(1 \mathrm{~mL})$ contained $75 \mu \mathrm{L}$ of extract, $775 \mu \mathrm{L}$ of $50 \mathrm{mM}$ sodium phosphate buffer (pH 7.0) and $150 \mu \mathrm{L}$ of 29 $\mathrm{mM} \mathrm{H}_{2} \mathrm{O}_{2}$. The decrease in absorbance was measured at $240 \mathrm{~nm}\left(\varepsilon=39.4 \mathrm{mM}^{-1} \mathrm{~cm}^{-1}\right)$. One unit of CAT was expressed as $1 \mu \mathrm{mol} \mathrm{H}_{2} \mathrm{O}_{2}$ degraded per minute at $25^{\circ} \mathrm{C}$.

Ascorbate peroxidase assay (APX; EC 1.11.1.11) 
APX activity was determined according to a modified protocol of Asada (1981). The standard reaction mixture $(1 \mathrm{~mL})$ contained $33 \mu \mathrm{L}$ of $10 \mathrm{mM}$ ascorbate, $20 \mu \mathrm{L}$ of $5 \mathrm{mM}$ Ethylenediaminetetraacetic acid (EDTA), $33 \mu \mathrm{L}$ of extract in $900 \mu \mathrm{L}$ of $90 \mathrm{mM}$ potassium phosphate buffer ( $\mathrm{pH}$ 7.0). The reaction was triggered when $14 \mu \mathrm{L}$ of $29 \mathrm{mM} \mathrm{H}_{2} \mathrm{O}_{2}$ was added. The rate of ascorbate oxidizing was evaluated at $290 \mathrm{~nm}$ for $3 \mathrm{~min}\left(\varepsilon=2.8 \mathrm{mM}^{-1} \mathrm{~cm}^{-1}\right)$. One unit of APX was expressed as the degradation of $1 \mu \mathrm{mol}$ ascorbate per minute at $25^{\circ} \mathrm{C}$.

\section{Monodehydroascorbate reductase assay (MDHAR; EC 1.6.5.4)}

MDHAR activity was measured by a modified procedure of Drew et al. (2007). $100 \mu \mathrm{L}$ of extract was added to $775 \mu \mathrm{L}$ of a solution containing $12.5 \mathrm{mM}$ potassium phosphate buffer composed of $0.125 \%$ Triton X100 (pH 8), $75 \mu \mathrm{L}$ of $32.5 \mathrm{mM}$ ascorbate, $40 \mu \mathrm{L}$ of 3.2 units ascorbate oxidase in a total volume of $1 \mathrm{~mL}$. The reaction was started by adding $13 \mu \mathrm{L}$ of $15 \mathrm{mM}$ Nicotinamide Adenine dinucleotide (NADH). The decrease in absorbance was measured at $340 \mathrm{~nm}\left(\varepsilon=6.3 \mathrm{mM}^{-1} \mathrm{~cm}^{-1}\right)$. One unit of MDHAR was defined as the amount of enzyme required to degrade $1 \mu$ mol NADH per minute at $340 \mathrm{~nm}$ at $25^{\circ} \mathrm{C}$.

\section{Dehydroascorbate reductase assay (DHAR; EC 1.8.5.1)}

DHAR activity was assayed by measuring the rate of apparition of ascorbate at $265 \mathrm{~nm}\left(\varepsilon=14.5 \mathrm{mM}^{-}\right.$ ${ }^{1} \mathrm{~cm}^{-1}$ ) (Asada 1984). The standard reaction mixture $(1 \mathrm{~mL})$ contained $820 \mu \mathrm{L}$ of $50 \mathrm{mM}$ potassium phosphate buffer ( $\mathrm{pH} 6.5$ ), $40 \mu \mathrm{L}$ of $125 \mathrm{mM}$ reduced glutathione (GSH), $15 \mu \mathrm{L}$ of $7.7 \mathrm{mM}$ EDTA, and $75 \mu \mathrm{L}$ of extract, with $50 \mu \mathrm{L}$ of $10 \mathrm{mM}$ dehydroascorbate (DHA) added to initiate the reaction. One DHAR unit was defined as the amount of enzyme which allows the formation of $1 \mu \mathrm{mol}$ ascorbate per minute at $25^{\circ} \mathrm{C}$.

\section{Glutathione reductase assay (GR; EC 1.6.4.2)}

GR activity was measured according to the modified method of Carlberg and Mannervik (1980). The standard reaction mixture $(1 \mathrm{~mL})$ contained $880 \mu \mathrm{L}$ of a solution composed of $160 \mathrm{mM}$ potassium phosphate buffer (pH 7) and $2 \mathrm{mM}$ EDTA, $10 \mu \mathrm{L}$ of $20 \mathrm{mM}$ glutathione disulfide (GSSG) and $100 \mu \mathrm{L}$ of extract. $10 \mu \mathrm{L}$ of $2 \mathrm{mM}$ NADPH was added to initiate the reaction. The decrease in absorbance was measured at $340 \mathrm{~nm}\left(\varepsilon=6.3 \mathrm{mM}^{-1} \mathrm{~cm}^{-1}\right)$. One GR unit was defined as the amount of enzyme required to degrade $1 \mu \mathrm{mol} \mathrm{NADPH}$ per minute at $340 \mathrm{~nm}$ at $25^{\circ} \mathrm{C}$.

\section{Protein assay}

Protein concentration in all extract was determined by the method of Bradford (1976) and enzymes activities were expressed in units. $\mathrm{mg}^{-1}$ protein (specific enzymatic activities).

All time course measurements were performed in a spectrophotometer Specord 205 (Analytic jena, Wembley, UK). 


\section{Sugar assay}

Sugar extraction was carried out according to the method of Gomez et al. (2002). A total of $100 \mathrm{mg}$ of lyophilized powder was homogenized in $5 \mathrm{~mL}$ of water, stirred and centrifuged at $400 \mathrm{~g}$ during 10 min. The supernatant was filtered through a cellulose acetate membrane (25 mm, $22 \mu \mathrm{m}$; VWR) and placed in a vial for HPLC analysis.

Sugars were analyzed by HPLC using a Perkin-Elmer series 200 refractometer (Waltham, USA) according to Gomez et al. (2002). Sugars were separated by a cation-exchange column [Sugar Pak I, $500 \times 3.5 \mathrm{~mm}$ (Waters, Mulfort, USA)]. The mobile phase was a disodium Ca-EDTA buffer at 50 $\mathrm{mg} \mathrm{L}^{-1}$. Chromatographic data was collected, stored and integrated using a TOTAL CHROM $^{\mathrm{TM}}$ version 6.2 software from Perkin-Elmer Instruments (Shelton, USA). Sugars were identified using their refractive index, and co-injection with authentic standards. Quantification of sugars was achieved using calibration curves with six concentrations. The concentration of each sugar was expressed on a fresh weight basis.

\section{Organic acid assay}

Organic acid extraction was carried out according to Albertini et al. (2006). A total of $100 \mathrm{mg}$ of lyophilized powder was homogenized in $5 \mathrm{~mL}$ of water, stirred and centrifuged at $400 \mathrm{~g}$ during 10 min. The supernatant was filtered through a cellulose acetate membrane (25 mm, $22 \mu \mathrm{m}$; VWR $)$ and placed in a vial for HPLC analysis.

Organic acids were analyzed by HPLC using a Perkin-Elmer series 200 UV-detector (Waltham, USA), according to Albertini et al. (2006). Organics acids were separated by reverse phase $C_{18}$ column (Spheri-5 RP 18, $220 \times 4.6 \mathrm{~mm}$, d.5 $\mu \mathrm{m}$; Perkin-Elmer). Absorbance was measured at $210 \mathrm{~nm}$ using a Perkin-Elmer series 200 UV-detector. Chromatographic data and UV spectra were collected, stored and integrated using the TOTAL $\mathrm{CHROM}^{\mathrm{TM}}$ version 6.2 software from Perkin-Elmer Instruments. Organic acids were identified using retention times and co-injection with authentic standards. Quantification of organics acids was achieved using calibration curves with six concentrations. The concentration of each organic acid was expressed on a fresh weight basis.

\section{Carotenoid assay}

Carotenoid extraction, identification and quantification were carried out according to the method of Fanciullino et al. (2008). $2.5 \mathrm{~g}$ of fresh matter was stirred with $120 \mathrm{mg}$ of $\mathrm{MgCO}_{3}$ and $35 \mathrm{~mL}$ of ethanol/hexane (4:3 v/v containing $0.1 \%$ BHT as antioxidant). Lycopene (300 $\mu \mathrm{L}$ of solution equivalent to $60 \mu \mathrm{g}$ ) was added as an internal standard. Residue was separated from the liquid phase by filtration with a filter funnel (porosity 2), re-extracted with $35 \mathrm{~mL}$ of ethanol/hexane and finally 30 $\mathrm{mL}$ of ethanol and $30 \mathrm{~mL}$ of hexane. Organic phases were transferred in a separatory funnel and successively washed with $2 \times 50 \mathrm{~mL}$ of $10 \%$ sodium chloride and $3 \times 50 \mathrm{~mL}$ of distilled water. The 
hexanic phase was dried, and redissolved with $20 \mathrm{~mL}$ of hexane and saponified with an equal volume of $10 \%$ methanolic $\mathrm{KOH}$, overnight, at room temperature, protected from the light. The sample was transferred to a separatory funnel to which $50 \mathrm{~mL}$ of distilled water was added to separate the layers. The hexanic layer was washed with distilled water until free of alkali. The methanolic $\mathrm{KOH}$ layer was extracted with $3 \times 10 \mathrm{~mL}$ of dichloromethane. The extracts were pooled and washed to remove alkali, dried using anhydrous sodium sulfate, filtered and evaporated in a rotary evaporator. The residue was dissolved in $500 \mu \mathrm{L}$ of dichloromethane and $500 \mu \mathrm{L}$ of MTBE/methanol $(80: 20 \mathrm{v} / \mathrm{v})$, and placed in amber vials before HPLC analysis.

Carotenoids were analyzed by high-performance liquid chromatography using a L-2455 Hitachi system (Tokyo, Japan). Carotenoids were separated along a $\mathrm{C}_{30}$ column $250 \times 4.6 \mathrm{~mm}$ id., $5 \mu \mathrm{m}$ YMC; EUROP GmbH). Carotenoids were separated using the following mobile phases: $\mathrm{H}_{2} \mathrm{O}$ as eluent

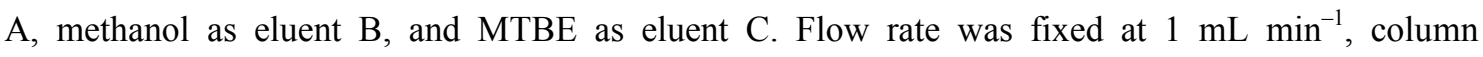
temperature was set at $25^{\circ} \mathrm{C}$, and injection volume was $20 \mu \mathrm{L}$. Absorbance was followed at 290, 350, 400, 450 and $470 \mathrm{~nm}$ using a L-2455 Hitachi photodiode array detector. Chromatographic data and UV-visible spectra were collected, stored and integrated using the EZCHROME version 6.8 software from VWR. Identification was carried out by HPLC-DAD through the combined use of the retention time, UV-visible spectral data, and co-injection with authentic standards. Quantification of carotenoids was achieved using a calibration curve with $\beta$-carotene at five concentration levels (correlation coefficient of 0.997). Limit of detection (LOD) and limit of quantification (LOQ) were calculated for $\beta$-carotene: LOD was $0.002 \mu \mathrm{g}$ and LOQ $0.007 \mu \mathrm{g}$. The carotenoids were quantified as $\beta$-carotene: the concentrations were expressed on a fresh weight basis. The total contents in carotenoids were calculated by summing the concentrations of all compounds.

\section{Statistical analyses}

Statistical analyses were performed using R statistical software (www.R-project.org). All results are expressed as mean \pm standard error (SE). Multiple mean comparisons were performed with the Kruskal-Wallis test at the $95 \%$ confidence level. To synthesize correlations between enzyme activities and metabolites across light treatments and exposure times, a principal component analysis (PCA) was performed on scaled and centered data.

\section{Results}

\section{Effect of leaf exposure to light on chlorophyll fluorescence parameters}

The maximum quantum yield of PSII $\left(\mathrm{F}_{\mathrm{v}} / \mathrm{F}_{\mathrm{m}}\right)$ was found to be ca. $20 \%$ lower in both FL and ML treatments when compared to the control, two days after exposure of the leaves to full and medium light conditions (Figure 1A). At that time, the Performance Index (PI) was also found to be much lower in both FL and ML treatments $(-76 \%$ and $-66 \%$ respectively) when compared to the control (Figure 1B). Although the FL leaves were slightly more affected than ML leaves in the subsequent days, this difference was not found to be significant. A decrease in PI may be attributable to a 
decrease in either the light reactions for primary photochemistry $\left(\mathrm{F}_{\mathrm{v}} / \mathrm{F}_{0}\right)$, the density of active reaction center on a chlorophyll basis (RC/ABS) or the dark reactions $\left(\left(1-\mathrm{V}_{\mathrm{J}}\right) / \mathrm{V}_{\mathrm{J}}\right)$. RC/ABS and $\mathrm{F}_{\mathrm{v}} / \mathrm{F}_{\mathrm{m}}$ followed the same pattern than PI (Figures 1C, 1D). Lower values for RC/ABS were observed from day $\mathrm{d}=2$ in both FL and ML treatments when compared to the control $(-36 \%)$. From day $d=2$ the decrease in $\mathrm{F}_{\mathrm{v}} / \mathrm{F}_{0}$ was especially pronounced: $-57 \%$ and $-46 \%$ for the FL and ML leaves, respectively. The contribution of $\left(1-\mathrm{V}_{\mathrm{J}}\right) / \mathrm{V}_{\mathrm{J}}$ to the PI profile was less important than the other parameters (Figure $1 \mathrm{E})$. When compared to the control, $\left(1-\mathrm{V}_{\mathrm{J}}\right) / \mathrm{V}_{\mathrm{J}}$ was significantly lower in the FL and ML treatments than in the control only at day $\mathrm{d}=4(-18 \%)$.

\section{Effect of leaf exposure to light on the activity of the antioxidant enzymes and $\mathrm{H}_{2} \mathrm{O}_{2}$ in the pulp of nearby fruits}

We investigated whether the light-induced photooxidative stress in the leaves could translate into changes in the antioxidant enzyme machinery in the pulp of nearby fruits. Specifically, we determined the activity of the ROS-scavenging enzymes SOD and CAT, as well as the enzymes of the ascorbateglutathione cycle (Figure 2). We also determined the concentration in $\mathrm{H}_{2} \mathrm{O}_{2}$ in the pulp of fruits (Figure 3). Three hours after exposure of the shaded leaves to light, the FL and ML treatments resulted in a higher SODt activity when compared to the control: $+58 \%$ and $+27 \%$, respectively (Figure 2A). There were substantial differences between the FL and ML treatments: $94.9 \pm 4.4$ vs. $76.1 \pm 3.5 \mathrm{U.mg}^{-1}$ protein, respectively. The activities of MnSOD and CAT were not or barely affected by the treatments (Figures 2B, 2C). In contrast, substantial changes in APX activity appeared early as a result of exposure of the leaves to light (Figure 2D). After only 3 hours, both FL and ML treatments resulted in a significantly higher activity when compared to the control. Twenty-seven hours after exposure of the leaves to light, APX activity was still higher in the pulp of the fruits from the FL and ML treatments $(+58 \%$ and $+26 \%$, respectively). There were significant differences between the FL and ML treatments: $5.66 \pm 0.1$ vs. $4.53 \pm 0.2 \mathrm{U.mg}^{-1}$ protein, respectively. APX activity in the FL treatment remained significantly higher than in the control throughout the whole period of observations. By contrast, the APX activity in the ML treatment was no more significantly different from the control 99 hours after exposure of the leaves. The activity of DHAR was slightly enhanced by the FL treatment throughout the experiment, but it was significantly different only 3 and 99 hours following leaf exposure (Figure 2E). By contrast, the activity of MDHAR was dramatically affected by both treatments, especially FL (Figure 2F). MDHAR activity in the control was on average $0.33 \pm 0.004 \mathrm{U.mg}^{-1}$ protein. It was significantly higher in both FL and ML treatments: $+388 \%$ and $+172 \%$ on average, respectively. This difference was apparent as soon as 3 hours after exposure of the leaves to light and lasted throughout the whole period of observations. There were significant

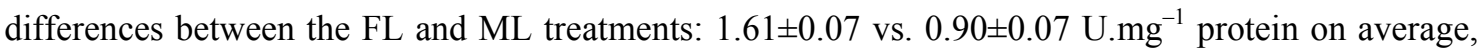
respectively. Changes in GR activity were observed in the FL and ML treatments, but only after 27 and 51 hours, respectively (Figure $2 \mathrm{G}$ ). After $51 \mathrm{~h}$, for instance, GR activity was +82 and $+39 \%$ higher 
in the FL and ML treatments, respectively, than in the control. After 27 hours, the concentration in $\mathrm{H}_{2} \mathrm{O}_{2}$ was ca. 20\% higher in the pulp of the FL than of the control fruits (Figure 3). After 99 hours, the difference was about $+30 \%$. $\mathrm{H}_{2} \mathrm{O}_{2}$ concentration was intermediate in the ML treatment, but was not significantly different neither from the FL treatment nor from the control.

\section{Effect on fruit quality criteria of leaf exposure to full light}

Because some redox-related enzymes of the fruit were shown to respond to light-induced photooxidative stress in the leaves, we studied to what extent these changes could affect the metabolism of the fruit. The treatments applied did not markedly impact the concentration in AA nor in total ascorbate (quantitatively driven by AA) (Figures 4A, 4B). However, the light treatments induced a decrease in DHA, especially in the FL treatment where DHA decreased after 27 hours and reached a minimum at 51 hours (-61\% when compared to the control) (Figure 4C).

Contents in sugars, organic acids and carotenoids of the fruit after 99-hour leaf exposure to light are presented in Figure 5. Whereas the concentration in total sugars was not significantly affected, the FL treatment (and the ML treatment to a lesser, non-significant extent) resulted in a moderate increase in sucrose $(+16 \%)$, apparently at the expense of glucose $(-11 \%)$ and fructose $(-13 \%)$ (Figure $5 \mathrm{~A})$. The FL as well as the ML treatments resulted in a $+16 \%$ increase in total acids when compared to the control, with succinic acid being the major contributor to the observed increase $(+27 \%$ for the FL treatment) (Figure 5B). Similarly, the FL treatment resulted in a $+15 \%$ increase in total carotenoids, the major quantitative contributor being cis-violaxanthin $(+20 \%)$. The concentrations of the other carotenoids also increased significantly, e.g. $+24 \%$ for lutein, $+23 \%$ for zeaxanthin, $+22 \%$ for zeinoxanthin, and $+17 \%$ for $\beta$-cryptoxanthin (Figure $5 \mathrm{C}$ ).

\section{Signaling from stressed leaves to nearby fruits}

Our observations on the enzymatic activities as well as on the metabolism were synthesized using a principal component analysis (PCA), which provides a global view of correlations between parameters (Figure 6A) and of the fruit response to exposure of leaves to light (Figure 6B). The first plane encompasses $60 \%$ of the total variance since the first and the second components (axis) take into account $43 \%$ and $16 \%$ of the data matrix total inertia respectively (Figure 6). Interestingly, the first principal component (PC1), which is the horizontal axis was positively correlated with DHA content, i.e. the oxidized form of ascorbate, and negatively with all the antioxidant enzyme activities (except CAT, weakly represented on the first plane). Thus, PC1 can be interpreted as an antioxidantrelated axis, with negative values being a global indicator of oxidative stress. Very clearly leaf exposure to light induced the parameters measured on fruits to shift towards negative values. This shift was more marked in the FL fruits than in the ML fruits, i.e. the samples of orange fruits were ordered along this horizontal axis (Figure 6B). Interestingly, this shift was accompanied by an increase in carotenoids (Figure 5C, Figure 6A). 


\section{Discussion}

\section{Exposure to light induced photooxidative stress in leaves}

Several parameters using fluorescence of chlorophyll $a$ emitted by photosystem II (PSII) were used as indicators of photooxidative stress.

At day $d=+2$, the maximum quantum yield of PSII $\left(\mathrm{F}_{\mathrm{v}} / \mathrm{F}_{\mathrm{m}}\right)$ was significantly lower in the FL and ML treatments when compared to the control. At day $d=+4, F_{v} / F_{m}$ was ca. $30 \%$ lower than in the control in both treatments (Figure 1A).

The Performance Index on an absorption basis, PI (Srivastava and Strasser 1999), based on the analysis of the OJIP fast fluorescence rise measured from $50 \mathrm{~ms}$ to $1 \mathrm{~s}$ upon illumination of photosynthetic samples (Strasser et al. 2000), is considered as a much more sensitive and discriminating stress indicator than $\mathrm{F}_{\mathrm{v}} / \mathrm{F}_{\mathrm{m}}$ (Thach et al. 2007). Indeed, at day $\mathrm{d}=+4$, PI was $78 \%$ and $60 \%$ lower in the FL and the ML treatments, respectively, when compared to the control (Figure 1B). $\mathrm{PI}$ is a multi-parametric expression of three independent steps contributing to photosynthesis, namely RC/ABS, $F_{\mathrm{v}} / F_{0}$ and $\left(1-\mathrm{V}_{\mathrm{J}}\right) / \mathrm{V}_{\mathrm{J}}$. RC/ABS represents the contribution to the PI of the density of active reaction centers (in the sense of $\mathrm{Q}_{\mathrm{A}}$ reducing) on a chlorophyll basis. A decrease of RC/ABS means an increase in the size of the chlorophyll antenna serving each reaction center. $F_{v} / F_{0}$ represents the contribution to the PI of the light reactions for primary photochemistry, i.e. the performance due to the trapping probability. $\left(1-\mathrm{V}_{\mathrm{J}}\right) / \mathrm{V}_{\mathrm{J}}$ represents the contribution of the dark reactions to the PI, or, in other words, the performance due to the conversion of excitation energy to photosynthetic electron transport. Clearly, the decrease of PI in the two light treatments is attributable above all to a decrease in the trapping probability $\left(\mathrm{F}_{\mathrm{v}} / \mathrm{F}_{0}\right)$, secondarily to a decrease in RC/ABS, and not at all to a decrease in dark reactions after $\mathrm{Q}_{\mathrm{A}}{ }^{-}$. The response we observed is consistent with what we currently know about photoinhibition (Critchley and Raghavendra 1998, Hikosaka 2004, Lambers et al. 1998, Loreto et al. 2004) and also with other similar studies (Thach et al. 2007). The decrease in the trapping probability and in $\mathrm{RC} / \mathrm{ABS}$ represent both adaptative responses aiming at reducing photodamage while preserving photosynthetic productivity in conditions characterized by an excess of absorbed energy

with respect to the quantity which can be utilized by photosynthesis. Our observations clearly demonstrate that the light treatments applied to previously shaded leaves provoke photoinhibition for at least 99 hours. Although the measured parameters were not significantly different between the ML and FL treatments, the chronological pattern of $F_{v} / F_{0}$ suggests that the stressing conditions were more severe in the FL than in the ML treatment.

\section{Photooxidative stress in leaves impacts the metabolism in the pulp of nearby fruits}

After having characterized the photooxidative stress induced in the leaves by the light treatments, we tested the hypothesis that stress in leaves modifies the metabolism in the pulp of nearby, non-shaded fruits. We analyzed soluble sugars, organic acids and carotenoids. We moreover analyzed the $\mathrm{H}_{2} \mathrm{O}_{2}$ 
concentration and the enzymes of the antioxidant machinery by focusing on the ROS-scavenging enzymes SOD and CAT, as well as the enzymes of the ascorbate-glutathione cycle.

Our observations clearly show that the metabolism in the pulp of fruits close to leaves undergoing photooxidative stress was modified, since we observed a shift towards less glucose + fructose and more sucrose (Figure 5A), an increase in organic acids (Figure 5B), and an increase in carotenoids (Figure 5C). In addition, SODt was substantially higher in the ML and FL treatments, especially in the latter one, $3 \mathrm{~h}$ after leaf exposure to light (Fig. 2A), suggesting that fruits had to deal with an increase in concentration of anion superoxide, at least at the beginning of the period of imposed stress. Moreover hydrogen superoxide concentration, $\left[\mathrm{H}_{2} \mathrm{O}_{2}\right]$, was significantly, if only slightly, higher in the FL treatment when compared to the control from $t=27 \mathrm{~h}$ (Fig. 3). SOD converts anion superoxide to $\mathrm{H}_{2} \mathrm{O}_{2}$, but it is not clear whether the higher concentration in $\mathrm{H}_{2} \mathrm{O}_{2}$ we observed in our trial is attributable to either increased SOD activity, or possibly to the fact that $\mathrm{H}_{2} \mathrm{O}_{2}$ was imported from stressed leaves, or both, considering that it is well demonstrated that $\mathrm{H}_{2} \mathrm{O}_{2}$ can be involved in short to medium distance signaling (Neill et al. 2002). At any rate, these two last observations about increased SOD activity and increased $\left[\mathrm{H}_{2} \mathrm{O}_{2}\right]$, suggest that oxidative stress was somehow imported from the stressed leaves to the pulp of nearby fruits. We shall now discuss the way the increase in $\left[\mathrm{H}_{2} \mathrm{O}_{2}\right]$ was dealt with by the antioxidant enzymes and systems in the pulp, and see whether we can conclude that oxidative stress really occurred, before discussing the possible implications of oxidative stress in the observed changes in concentrations in carotenoids which appeared in the pulp of the fruits of the FL and, to a lesser extent, ML treatments.

\section{Can we conclude to oxidative stress in the pulp of fruits?}

$\mathrm{H}_{2} \mathrm{O}_{2}$ produced by SOD can be eliminated by catalase (CAT) and also by ascorbate peroxidase (APX) of the ascorbate-glutathione cycle. Clearly CAT activity was not modified neither in the FL nor in the ML treatments in our trial, which is consistent with the observations made on tobacco leaves submitted to high light conditions (Willekens et al. 1997). By contrast, the activity of APX was increased in the FL and ML treatments. This is consistent with the commonly admitted idea that APX activity generally increases in response to environmental stresses (Shigeoka et al. 2002), on the contrary to CAT (Mittler 2002). Certainly CAT activity increases in peroxisomes as the consequence of stress-associated increases in photorespiration, but then photorespiration could not have increased in the pulp of the orange fruits of our study, since the latter had reached the maturation phase. At that stage all chloroplasts had evolved into chromoplasts and there was no operational photosynthetic machinery present any more. This may well explain why CAT activity was found unaffected by both the ML and FL treatments.

In plants submitted to environmental stresses, an increase in activity of APX is often associated with a higher level of oxidation of the ascorbate pool, which we clearly did not observe here (Fig. 4). Two enzymes are involved in the regeneration of ascorbate (AA) oxidized by APX into MDHA: 
MDHAR and DHAR (Foyer and Noctor 2003). MDHA can be converted either enzymatically into AA by MDHAR (Mittova et al. 2000, Shalata and Tal 1998, Shalata et al. 2001) or non-enzymatically into AA + DHA. Then DHA is converted into AA by DHAR while GSH is oxidized into GSSG (Urano et al. 2000, Ushimaru et al. 1992). GR then reduces GSSG in the presence of NAD(P)H. The activity of MDHAR was stimulated in the ML and FL treatments much more than the activity of DHAR (Figs. 2E and 2F), indicating that regeneration of the ascorbate pool is attributable to MDHAR activity more than to DHAR (and GR) activities in our study. Also, our results show that regeneration of the ascorbate pool by APX and MDHAR was effective in maintaining $\left[\mathrm{H}_{2} \mathrm{O}_{2}\right]$ more or less constant in each treatment. Now, it is interesting to observe that these mechanisms did not prevent $\left[\mathrm{H}_{2} \mathrm{O}_{2}\right]$ to be higher, if only slightly, in the pulp of the fruits close to the stressed leaves. The differences in $\left[\mathrm{H}_{2} \mathrm{O}_{2}\right]$ between treatments clearly result from the stress imposed to nearby leaves. Being low, these differences cannot be interpreted in terms of oxidative stress, but they may well be associated to signaling and to the differences in concentrations in metabolites we observed.

\section{Interpreting the stimulating effect of stressing leaves on carotenoid synthesis in the pulp of nearby fruits}

We have no explanations to provide for the observed differences in primary metabolites between treatments. But the stimulating effect of stressing conditions imposed to leaves on the concentration in carotenoids in the pulp of nearby fruits could be considered as consistent with the "imported oxidative stress" theory. Indeed, since several enzyme activities of the antioxidant machinery in the pulp of orange fruits were strongly affected by the stress treatments, especially FL, it is tempting to interpret the effect of a photoinhibitory stress applied to leaves on the synthesis of carotenoids of fruits in the light of what we know about the effect of oxidative stress and the associated changes in redox status on the biosynthetic pathway of carotenoids. The prevailing view is that the entire biosynthetic pathway of carotenoids is under redox control (Steinbrenner and Linden 2003). This is the case of phytoene synthase (PSY) and phytoene desaturase (PDS), the two enzymes exerting the greatest control over the biosynthetic pathway of carotenoids (Fraser et al. 2007, Fraser et al. 2002). The hypothesis that leaves undergoing photoinhibition influence redox signaling in fruits has a lot of appeal as some of the systems involved in redox signaling were shown to operate as important modulators of the plant response to hormones (Lushchak 2011).

Taken together our study clearly demonstrates that the ROS/antioxidant metabolism was deeply modified in the pulp of fruits close to leaves submitted to conditions conducive to photooxidative stress. In point of fact, it is the whole metabolism of the pulp of the fruits close to leaves submitted to high light conditions which appears to have been modified, both the primary and the secondary metabolisms, since we observed a shift towards less glucose+fructose and more sucrose, an increase in organic acids and an increase in carotenoids. This raises intriguing questions about the signaling behind the observed response in fruits. Could possibly ROS have been exported from the stressed 
leaves to nearby fruits? Alternatively, could a signal have been generated in the stressed leaves and then transmitted to nearby fruits with the effect of triggering there the production of ROS? Were signaling molecules other than ROS involved? The applied consequences are also fascinating. Considering that most stresses in plants result in photooxidative stress (Grassmann et al. 2002), it may be tempting to exploit stressing conditions to influence quality criteria, and possibly the concentration of carotenoids in fruits. For instance, water stress, limited in time and intensity, could be easily applied by growers, even in field conditions. Using mild water stress as a lever to increase quality of fruits will require to improve our knowledge about the relevant physiological processes involved, and our understanding about the way stressing conditions precisely influence them.

Acknowledgments - We thank S. Antoine for her assistance. This study was partly supported by the 2007-2013 Interreg IVA program "France-Italie Maritime” (Project number B5H10000000006).

\section{References}

Aebi H (1984) Catalase in vitro Methods Enzymol 105: 121-126

Albertini MV, Carcouet E, Pailly O, Gambotti C, Luro F, Berti L (2006) Changes in organic acids and sugars during early stages of development of acidic and acidless citrus fruit. J Agric Food Chem 54: $8335-8339$

Asada K (1984) Chloroplasts: formation of active oxygen and its scavenging. Methods Enzymol 105: $422-429$

Bouvier F, Backhaus RA, Camara B (1998) Induction and control of chromoplast-specific carotenoid genes by oxidative stress. J Biol Chem 273: 30651-30659

Bradford MM (1976) Rapid and sensitive method for quantification of microgram quantities of protein utilizing principle of protein-dye binding Anal Biochem 72: 248-254

Carlberg I, Mannervik B (1980) Oxidase activity of glutathione reductase effected by 2,4,5trinitrobenzenesulfonate. FEBS letters 115: 265-268

Critchley C (1998) Photoinhibition. In: Rhagavendra AS (ed) Photosynthesis: a comprehensive treatise. Cambridge University Press, Cambridge, UK, pp 264-272

Demmig-Adams B, Adams WW (1996) The role of xanthophyll cycle carotenoids in the protection of photosynthesis. Trends Plant Sci 1: 21-26

Drew DP, Lunde C, Lahnstein J, Fincher GB (2007) Heterologous expression of cDNAs encoding monodehydroascorbate reductases from the moss, Physcomitrella patens and characterization of the expressed enzymes. Planta 225: 945-954

Fanciullino AL, Cercos M, Dhuique-Mayer C, Froelicher Y, Talon M, Ollitrault P, Morillon R (2008) Changes in carotenoid content and biosynthetic gene expression in juice sacs of four orange varieties (Citrus sinensis) differing in flesh fruit color. J Agric Food Chem 56: 3628-3638

Foyer CH, Noctor G (2003) Redox sensing and signalling associated with reactive oxygen in 
chloroplasts, peroxisomes and mitochondria. Physiol Plant 119: 355-364

Fraser PD, Enfissi EMA, Halket JM, Truesdale MR, Yu DM, Gerrish C, Bramley PM (2007)

Manipulation of phytoene levels in tomato fruit: Effects on isoprenoids, plastids, and intermediary metabolism. Plant Cell 19: 4131-4132

Fraser PD, Romer S, Shipton CA, Mills PB, Kiano JW, Misawa N, Drake RG, Schuch W, Bramley

PM (2002) Evaluation of transgenic tomato plants expressing an additional phytoene synthase in a fruit-specific manner. Proc Natl Acad Sci USA 99: 1092-1097

Gillespie KM, Ainsworth EA (2007) Measurement of reduced, oxidized and total ascorbate content in plants. Nat Protoc 2: 871-874

Gomez L, Rubio E, Auge M (2002) A new procedure for extraction and measurement of soluble sugars in ligneous plants. J Sci Food Agric 82: 360-369

Grassmann J, Hippeli S, Elstner EF (2002) Plant's defence and its benefits for animals and medicine: role of phenolics and terpenoids in avoiding oxygen stress. Plant Physiol Biochem 40: 471-478

Hikosaka K (2004) Interspecific difference in the photosynthesis-nitrogen relationship: patterns, physiological causes, and ecological importance. J Plant Res 117: 481-494

Jing M, Herbette S, Vandame M, Kositsup B, Kasemsap P, Cavaloc E, Julien J, Améglio T, RoeckelDrevet P (2009) Effect of chilling on photosynthesis and antioxidant enzymes in Hevea brasiliensis Muell. Arg Trees: Structure and Function 23: 863-874

Karpinski S, Reynolds H, Karpinska B, Wingsle G, Creissen G, Mullineaux P (1999) Systemic signaling and acclimation in response to excess excitation energy in Arabidopsis. Science 284: 654-657

Kuntz M, Chen HC, Simkin AJ, Romer S, Shipton CA, Drake R, Schuch W, Bramley PM (1998) Upregulation of two ripening-related genes from a nonclimacteric plant (pepper) in a transgenic climacteric plant (tomato). Plant J 13: 351-361

Lambers H, Chapin FS, Pons TL (1998) Plant physiological ecology. Springer, New York

Loreto F, Pinelli P, Manes F, Kollist H (2004) Impact of ozone on monoterpene emissions and evidence for an isoprene-like antioxidant action of monoterpenes emitted by Quercus ilex leaves. Tree Physiol 24: 361-367

Lushchak VI (2011) Adaptive response to oxidative stress: Bacteria, fungi, plants and animals. Compar Biochem Physiol C-Toxicol Pharmacol 153: 175-190

Mittler R (2002) Oxidative stress, antioxidants and stress tolerance. Trends Plant Sci 7: 405-410

Mittova V, Volokita M, Guy M, Tal M (2000) Activities of SOD and the ascorbate-glutathione cycle enzymes in subcellular compartments in leaves and roots of the cultivated tomato and its wild salt-tolerant relative Lycopersicon pennellii. Physiol Plant 110: 42-51

Monteith JL (1965) Evaporation and environment. Symp Soc Exp Biol 19: 205-34

Neill S, Desikan R, Hancock J (2002) Hydrogen peroxide signalling. Curr Opin Plant Biol 5: 388-395

Newell-McGloughlin M (2008) Nutritionally improved agricultural crops. Plant Physiol 147: 939-953 
Oberley LW, Spitz DR (1984) Assay of superoxide dismutase activity in tumor tissue. Methods Enzymol 105: 457-464

Poiroux-Gonord F, Bidel LPR, Fanciullino A-L, Gautier H, Lauri-Lopez F, Urban L (2010) Health benefits of vitamins and secondary metabolites of fruits and vegetables and prospects to increase their concentrations by agronomic approaches. J Agric Food Chem 58: 12065-12082

Rossel JB, Wilson PB, Hussain D, Woo NS, Gordon MJ, Mewett OP, Howell KA, Whelan J, Kazan K, Pogson BJ (2007) Systemic and intracellular responses to photooxidative stress in Arabidopsis. Plant Cell 19: 4091-4110

Ryals JA, Neuenschwander UH, Willits MG, Molina A, Steiner HY, Hunt MD (1996) Systemic acquired resistance. Plant Cell 8: 1809-1819

Shalata A, Tal M (1998) The effect of salt stress on lipid peroxidation and antioxidants in the leaf of the cultivated tomato and its wild salt-tolerant relative Lycopersicon pennellii. Physiol Plant 104: $169-174$

Shalata A, Mittova V, Volokita M, Guy M, Tal M (2001) Response of the cultivated tomato and its wild salt-tolerant relative Lycopersicon pennellii to salt-dependent oxidative stress: The root antioxidative system. Physiol Plant 112: 487-494

Shigeoka S, Ishikawa T, Tamoi M, Miyagawa Y, Takeda T, Yabuta Y, Yoshimura K (2002) Regulation and function of ascorbate peroxidase isoenzymes. J Exp Bot 53: 1305-1319

Srivastava A, Strasser RJ (1999) Greening of Peas: Parallel Measurements of 77 K Emission Spectra, OJIP Chlorophyll a Fluorescence Transient, Period Four Oscillation of the Initial Fluorescence Level, Delayed Light Emission, and P700. Photosynthetica 37: 365-392

Steinbrenner J, Linden H (2003) Light induction of carotenoid biosynthesis genes in the green alga Haematococcus pluvialis: regulation by photosynthetic redox control. Plant Mol Biol 52: 343356

Strasser R, Srivastava A, Tsimilli-Michael M (2000) The fluorescence transient as a tool to characterize and screen photosynthetic samples. In: Yunus M, Pathre U, Mohanty P (eds) Probing photosynthesis: mechanisms, regulation and adaptation. Taylor \& Francis, London, UK, pp 445-483

Tattini M, Galardi C, Pinelli P, Massai R, Remorini D, Agati G (2004) Differential accumulation of flavonoids and hydroxycinnamates in leaves of Ligustrum vulgare under excess light and drought stress. New Phytol 163: 547-561

Thach LB, Shapcott A, Schmidt S, Critchley C (2007) The OJIP fast fluorescence rise characterizes Graptophyllum species and their stress responses. Photosynth Res 94: 423-436

Urano J, Nakagawa T, Maki Y, Masumura T, Tanaka K, Murata N, Ushimaru T (2000) Molecular cloning and characterization of a rice dehydroascorbate reductase. FEBS Lett 466: 107-111

Ushimaru T, Shibasaka M, Tsuji H (1992) Development of the $\mathrm{O}_{2}^{-}$detoxification system during adaptation to air of submerged rice seedlings. Plant Cell Physiol 33: 1065-1071 
Velikova V, Yordanov I, Edreva A (2000) Oxidative stress and some antioxidant systems in acid raintreated bean plants: Protective role of exogenous polyamines. Plant Science 151: 59-66

Willekens H, Chamnongpol S, Davey M, Schraudner M, Langebartels C, VanMontagu M, Inze D, VanCamp W (1997) Catalase is a sink for $\mathrm{H}_{2} \mathrm{O}_{2}$ and is indispensable for stress defence in $\mathrm{C}_{3}$ plants. Embo J 16: 4806-4816

Zhu JJ, Zhang JL, Liu HC, Cao KF (2009) Photosynthesis, non-photochemical pathways and activities of antioxidant enzymes in a resilient evergreen oak under different climatic conditions from a valley savanna in Southwest China. Physiol Plant 135: 62-72

\section{Supporting Information}

Additional Supporting Information may be found in the online version of this article:

Appendix S1 Concentrations in carotenoids in the pulp of 'Navelate' orange fruits.

Appendix S2 $\mathrm{H}_{2} \mathrm{O}_{2}$ standard curve.

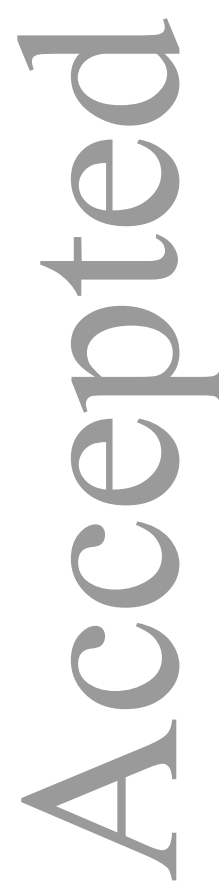

Please note: Wiley-Blackwell are not responsible for the content or functionality of any supplementary materials supplied by the authors. Any queries (other than missing material) should be directed to the corresponding author for the article.

Edited by A. Krieger-Liszkay 
Table 1. Meteorological data, from 3 to 13 February 2009, at San Giuliano (Corsica, France). $T_{\min }$ : minimum daily temperature; $T_{\max }$ : maximum daily temperature; $T_{\text {mean }}$ : mean daily temperature.

\begin{tabular}{|c|c|c|c|c|c|c|}
\hline & & $\mathrm{T}_{\min }\left({ }^{\circ} \mathrm{C}\right)$ & $\mathrm{T}_{\max }\left({ }^{\circ} \mathrm{C}\right)$ & $\mathrm{T}_{\text {mean }}\left({ }^{\circ} \mathrm{C}\right)$ & Rainfalls (mm) & $\begin{array}{l}\text { Daily global } \\
\text { radiation } \\
\left(\mathrm{J} \mathrm{cm}^{-2}\right)\end{array}$ \\
\hline \multirow{6}{*}{ 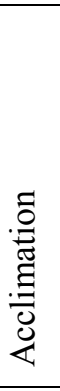 } & February, 3 & 6.3 & 15.0 & 10.2 & 0 & 854 \\
\hline & February, $4(\mathrm{~d}=-5)$ & 6.0 & 15.6 & 10.8 & 0 & 991 \\
\hline & February, 5 & 6.1 & 18.4 & 11.9 & 1 & 818 \\
\hline & February, 6 & 8.1 & 18.0 & 12.6 & 0 & 733 \\
\hline & February, 7 & 6.4 & 15.1 & 9.7 & 0.5 & 1101 \\
\hline & February, 8 & 3.1 & 13.7 & 8.2 & 0 & 1061 \\
\hline \multirow{5}{*}{ 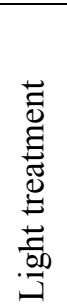 } & February, $9(\mathrm{~d}=0)$ & 4.2 & 15.2 & 8.9 & 0 & 1174 \\
\hline & February, 10 & 6.5 & 19.1 & 12.0 & 0 & 830 \\
\hline & February, $11(\mathrm{~d}=+2)$ & 5.3 & 11.8 & 9.0 & 0.5 & 482 \\
\hline & February, $12(\mathrm{~d}=+3)$ & 3.8 & 11.5 & 7.2 & 0.5 & 849 \\
\hline & February, $13(\mathrm{~d}=+4)$ & 1.7 & 8.9 & 4.1 & 0 & 713 \\
\hline
\end{tabular}




\section{Figure legends}

Figure 1. Light-induced photooxidative stress in leaves as revealed by chlorophyll fluorescence parameters. A. Maximum quantum yield of photosystem II $\left(\mathrm{F}_{\mathrm{v}} / \mathrm{F}_{\mathrm{m}}\right)$. B. Performance Index (PI) and its components: C. RC/ABS, D. $F_{v} / F_{0}$, E. $\left(1-V_{J}\right) / V_{J}$. Measurements were performed at $d=5, d=0, d=+2$, $\mathrm{d}=+3$ and $\mathrm{d}=+4)$. Data are means $\pm \mathrm{SE}(\mathrm{n}=15)$. Letters indicate significant differences between experimental conditions (treatment $\times$ exposure time) after a Kruskal-Wallis test at the $95 \%$ confidence level.

Figure 2. Fruit enzymatic machinery responds to leaf exposure to light. The activities of antioxidant enzymes and enzymes of the ascorbate-glutathione cycle was determined in the pulp of 'Navelate' orange fruits and expressed in $\mathrm{U} \mathrm{mg}^{-1}$ protein. Measurements were performed 3, 27, 51 and 99 hours after exposure of leaves to medium light, full light, or constant shade conditions (control). A. Total superoxide dismutase (SODt). B. Manganese superoxide dismutase (MnSOD). C. Catalase (CAT). D. Ascorbate peroxidase (APX). E. Monodehydroascorbate reductase (MDHAR). F. Dehydroascorbate reductase (DHAR). G. Glutathione reductase (GR). Data are means \pm SE ( $n=4)$. Letters indicate significant differences between experimental conditions (treatment $\times$ exposure time) after a KruskalWallis test at the $95 \%$ confidence level.

Figure 3. $\mathrm{H}_{2} \mathrm{O}_{2}$ concentrations of fruits after leaf exposure to light. Levels of $\mathrm{H}_{2} \mathrm{O}_{2}$ were determined in the pulp of 'Navelate' orange fruits and expressed in $\mu \mathrm{M} \mathrm{g}^{-1} \mathrm{FW}$. Measurements were performed 3, 27, 51 and 99 hours after exposure of leaves to medium light, full light, or constant shade conditions (control). Data are means \pm SE $(n=4)$. Letters indicate significant differences between experimental conditions (treatment $\times$ exposure time) after a Kruskal-Wallis test at the $95 \%$ confidence level.

Figure 4. Fruit ascorbate metabolism is affected by leaf exposure to light. Concentration of total ascorbate, reduced ascorbate and dehydroascorbate was determined in the pulp of 'Navelate' orange fruits and expressed in $\mu \mathrm{M} \mathrm{g}^{-1} \mathrm{FW}$. Measurements were performed 3, 27, 51 and 99 hours after exposure of leaves to medium light, full light, or constant shade conditions (control). A. Total ascorbate (AA + DHA). B. Reduced ascorbate (AA). C. Dehydroascorbate (DHA). Data are means \pm SE $(n=4)$. Letters indicate significant differences between experimental conditions (treatment $\times$ exposure time) after a Kruskal-Wallis test at the $95 \%$ confidence level. 
Figure 5. Fruit primary and secondary metabolisms are affected by leaf exposure to light. Concentration in soluble sugars (A), organic acids (B) and carotenoids (C) was determined in the pulp of 'Navelate' orange fruits after 99-hour exposure of leaves to medium light (hatched bars), full light (white bars), or constant shade conditions (control, black bars). Data are means \pm SE $(n=4)$. For each compound, letters indicate significant differences between light treatments after a Kruskal-Wallis test at the $95 \%$ confidence level.

Figure 6. Principal component analysis of the fruit response to leaf exposure to light. The first and second principal components (PCs) explained $42 \%$ and $17 \%$ of the total variance, respectively. A. Contribution of variables to PC1 and PC2. PC1 was positively correlated with dehydroascorbate (DHA) and negatively with total superoxide dismutase (SODt), glutathione reductase (GR), ascorbate peroxidase (APX), dehydroascorbate reductase (DHAR), monodehydroascorbate reductase (MDHAR), manganese superoxide dismutase (MnSOD), carotenoids and sugars. PC2 was positively correlated with reduced ascorbate (AA) and negatively with organic acids. Catalase (CAT) was poorly represented on the first plane. B. The contributions of individuals (treatment $\times$ exposure time) to PC1 and PC2 with the representation of treatment classes illustrated by inertia ellipses. 

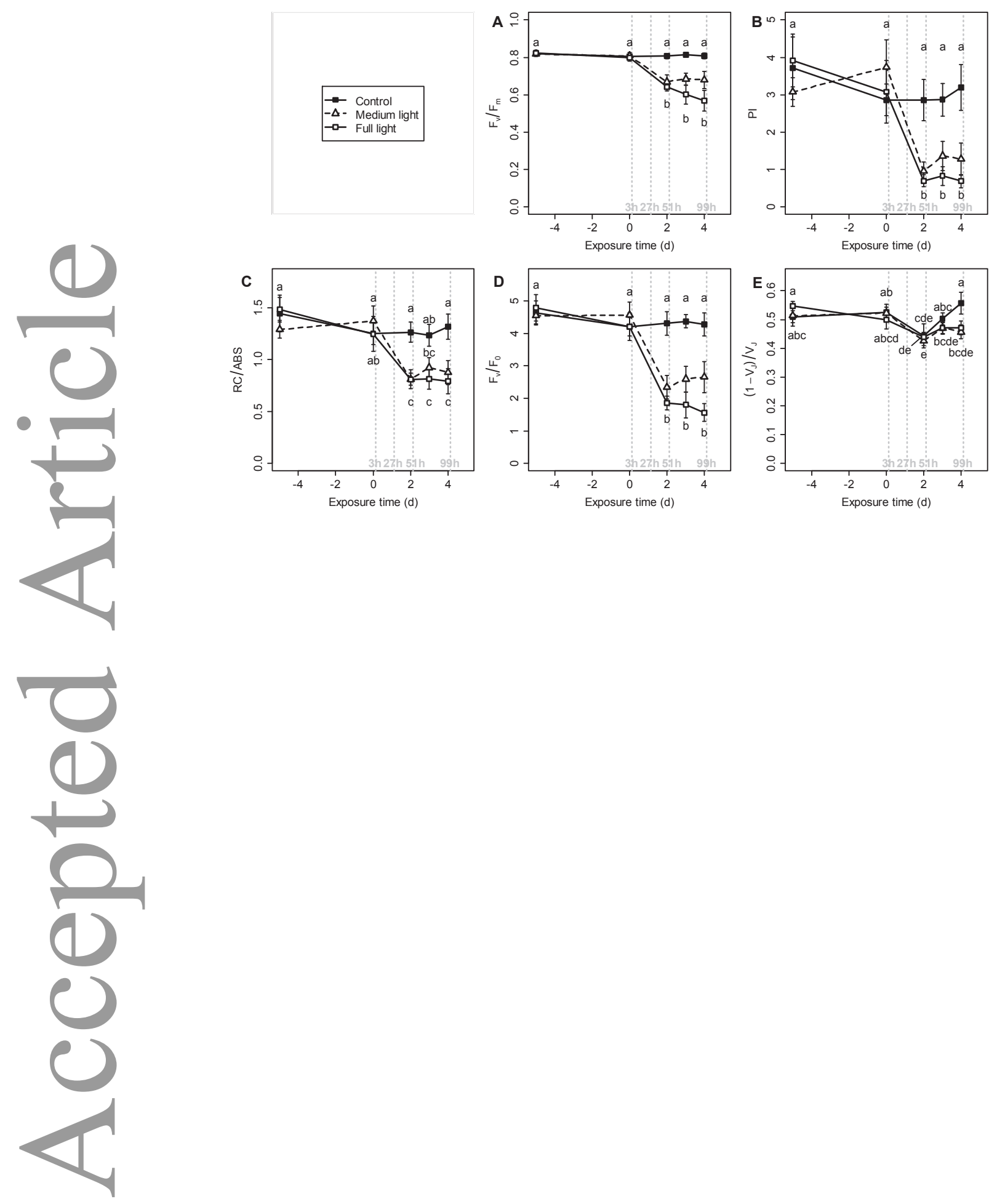

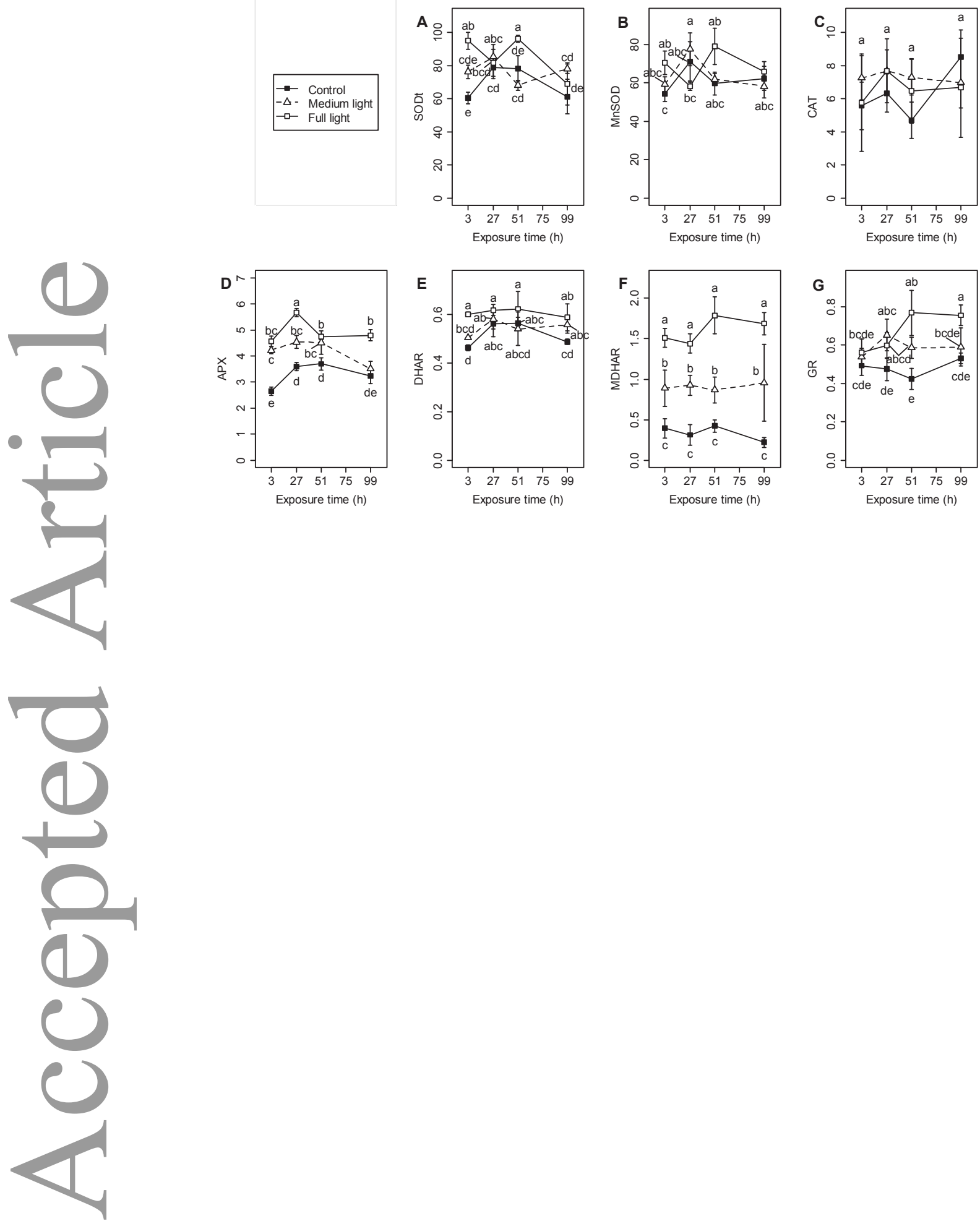


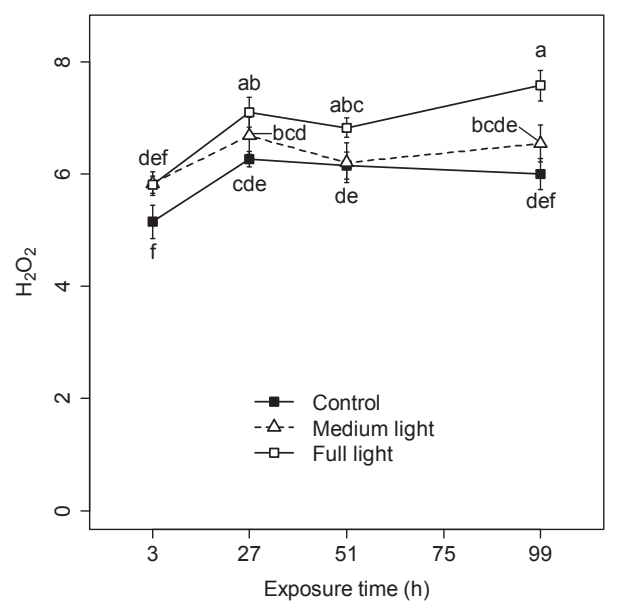

(2)
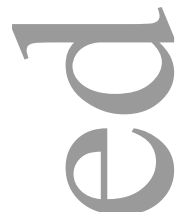

13

$\longrightarrow$

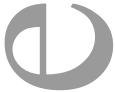

( )

( )

$+$ 

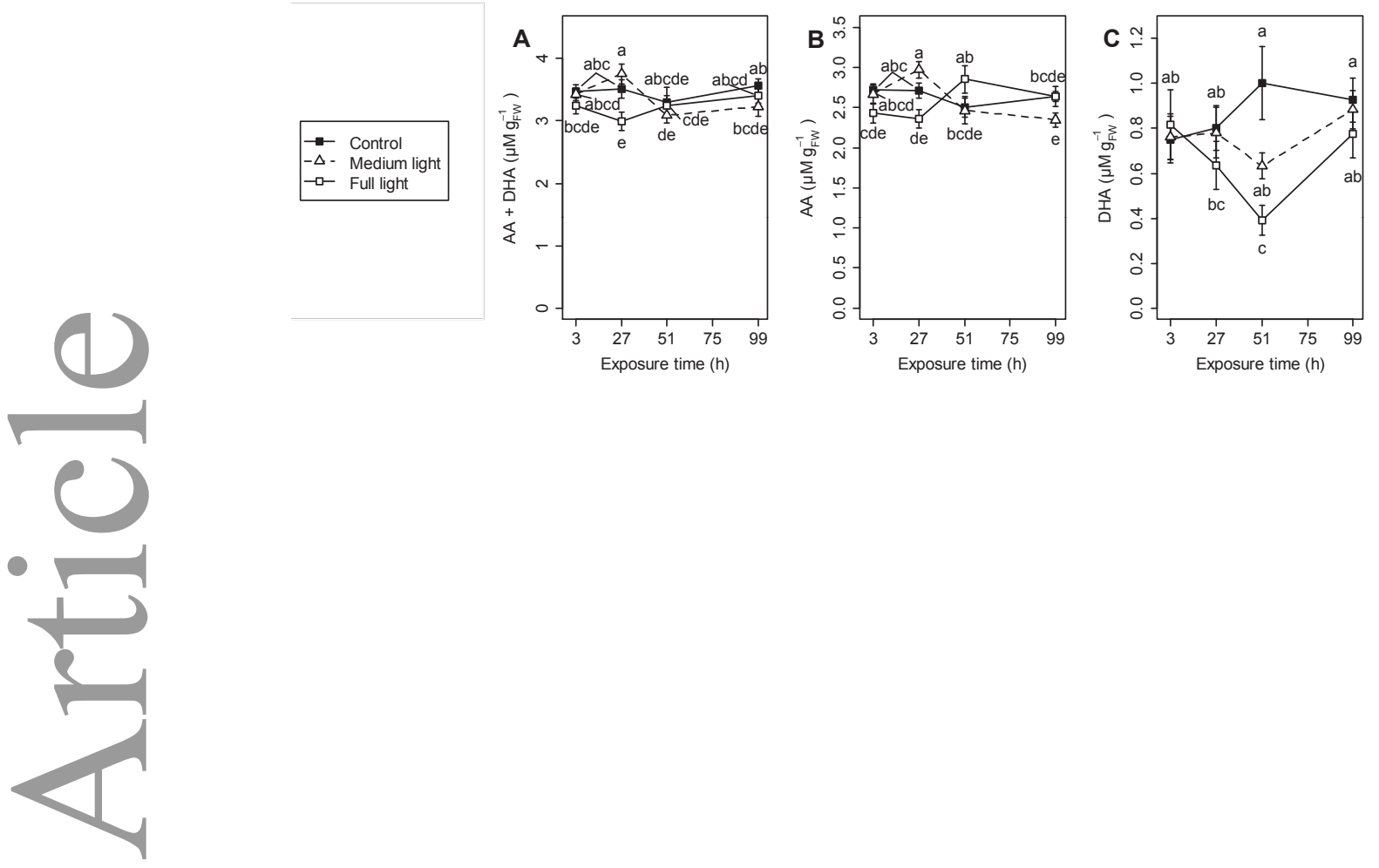

$\rightarrow-$ Control $\rightarrow-$ Full light

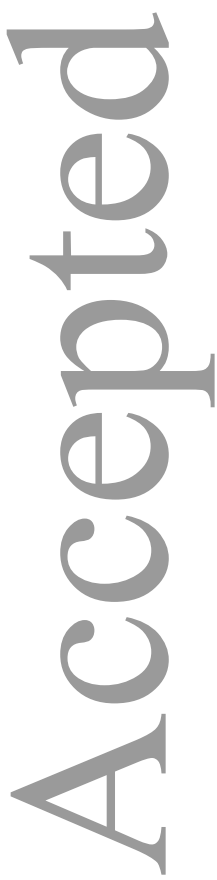



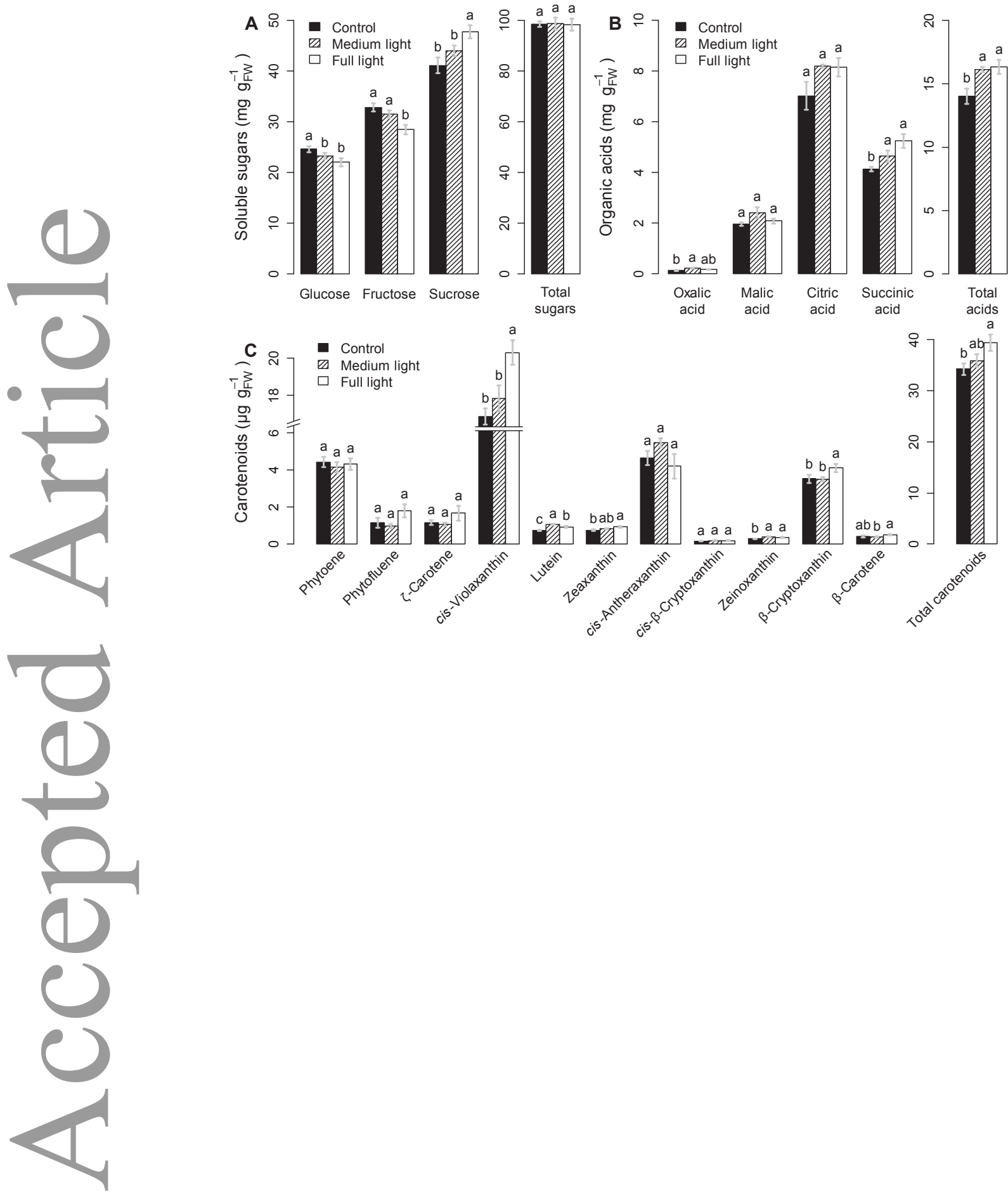


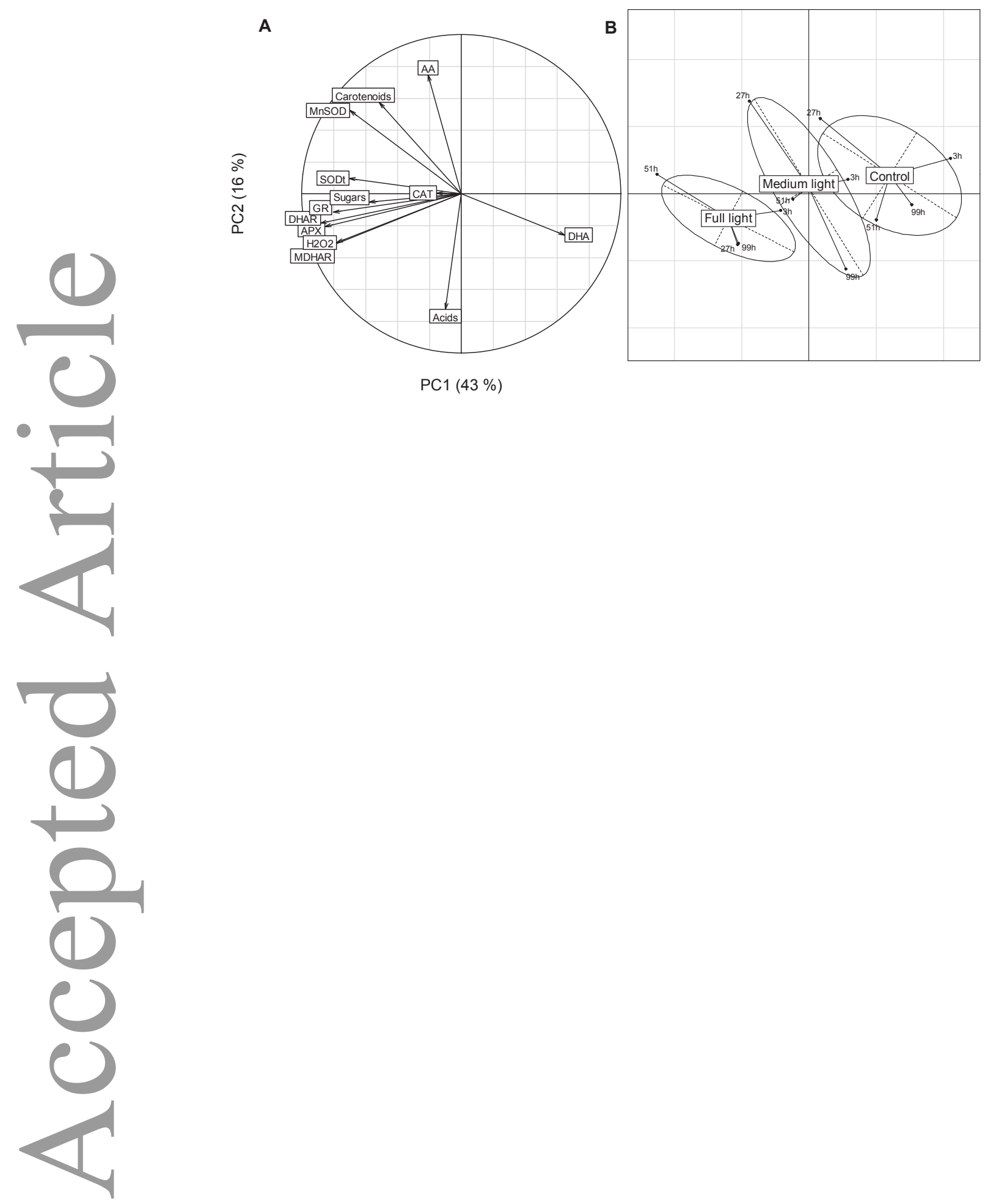

